\title{
AMMONIUM TOLERANCE IN LIVER DISEASE: OBSERVATIONS BASED ON CATHETERIZATION OF THE HEPATIC VEINS
}

\author{
By LAURENS P. WHITE, ${ }^{1}$ ELIZABETH A. PHEAR, ${ }^{2}$ W. H. J. SUMMERSKILL, \\ AND SHEILA SHERLOCK WITH THE TECHNICAL ASSISTANCE OF \\ MARJORIE COLE
}

(From the Department of Medicine, Post-Graduate Medical School, London, England)

(Submitted for publication June 28, 1954; accepted October 13, 1954)

The concept that substances from intestinal contents, passing into the general circulation, may cause toxic symptoms has been of particular interest in the study of liver disease. In 1896, Nencki, Pawlow, and Zaleski (1) demonstrated that diversion of portal blood, containing large amounts of ammonium, into the general circulation by an Eck fistula resulted in an increase in ammonium content of peripheral blood. In cirrhosis of the liver and in patients with porta-caval anastomoses elevation of blood ammonium has frequently been found and in some cases correlated with neurological disturbances (2-10).

The reason for the elevation of blood ammonium in these cases has not been determined precisely. Van Caulaert, Deviller, and Halff $(3,10)$ suggested that in cirrhosis this abnormality of ammonium was related to the presence of portal collateral veins with shunting of portal blood directly into the systemic circulation. Kirk (2) supported this hypothesis with extensive studies.

To evaluate the roles of portal collateral circulation and of liver function in the control of blood ammonium levels, simultaneous sampling from antecubital and hepatic veins has been undertaken. To accentuate differences in ammonium content at these sites, and to test patients' ability to metabolize ammonium, a standard dose of ammonium chloride has been given by mouth. The results of such investigations, with corollary observations, form the basis of this report.

\footnotetext{
1 British-American Exchange Fellow of the American Cancer Society. Present Address: National Cancer Institute, NIH, Bethesda, Md.

${ }^{2}$ Lund Research Fellow, of the Diabetic Association (Great Britain) to which we are also indebted for an expenses grant.
}

\section{$A$ note on the measurement of ammonium in the blood}

The measurement of blood ammonium is a flight after a Will-o'-th'-wisp (11), for it is generally agreed that ammonium is liberated as soon as blood is shed. Therefore, any single measurement made after drawing blood represents only a point on an ascending line of ammonium concentration.

By making timed serial determinations on the same sample of blood Conway and Cooke $(12,13)$ were able to construct a graph expressing the evolution of ammonium. From this graph, by extrapolation, they estimated the ammonium level at zero time, and concluded that there was no measurable ammonium in the circulating blood of normal individuals; they stressed that what was frequently measured as blood ammonium was in reality ammonium which had been liberated from other substances after the blood was drawn.

Conway and Cooke (13) found that blood drawn in an atmosphere of $\mathrm{CO}_{2}$ did not liberate ammonium immediately, and suggested that $\mathrm{CO}_{2}$ inhibited the breakdown of adenosine, which they had found to be the major source of the immediately liberated ammonium (14). Strehler, Haas, and Rupp (15) reported similar results and found that an atmosphere of $\mathrm{CO}_{2}$ would decrease the ammonium content of blood drawn in air. This depression of ammonium liberation was presumed to act through an inhibition of an enzyme deaminating adenosine. Kalckar (16) found that $\mathrm{CO}_{2}$ did not inhibit the deamination of adenosine by adenosine deaminase, nor did it catalyse reamination. In the present study no consistent significant inhibition of ammonium formation by $\mathrm{CO}_{2}$ could be demonstrated. Other workers $(6,17)$ even though taking blood in an atmosphere of $\mathrm{CO}_{2}$ have found high levels of ammonium in normal 
blood, suggesting that $\mathrm{CO}_{2}$ failed to inhibit ammonium liberation. We were also unable to suppress ammonium liberation by $\mathrm{AgNO}_{3}$ which Zittle (18) found completely inhibited adenosine deaminase. Accordingly, in the results reported here blood was drawn in air, and no attempt to inhibit ammonium liberation was made.

In the present study the technique of serial ammonium determinations on the same blood sample has been used. Each determination was timed from the moment of beginning the collection of blood until an aliquot was pipetted into the diffusion chamber. Six analyses were made on each sample, and a graph was constructed expressing the changing concentration of ammonium. The extrapolated zero-time ammonium was determined, and the observations on 21 control subjects without hepatic disease (including 15 normals) supported Conway's conclusion that in the fasting subject without liver disease there is no measurable free ammonium in the circulating blood (Figure 1).

This method of performing ammonium determinations made it very obvious that substances other than ammonium were being measured. The nature of these compounds is not known, although adenosine may be one. The present data again demonstrated that, whatever the sources of

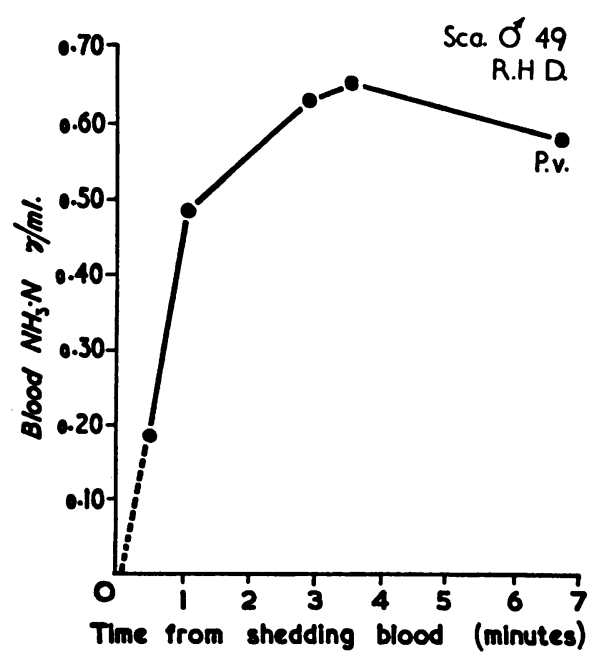

Fig. 1. Demonstration of the Changing Ammonium Content of a Single Blood Specimen, Plotted Against Time from Shedding

This chart is representative of others in patients without liver disease. RHD signifies Rheumatic Heart Disease. what was measured as ammonium, the liberation was very rapid. Three minutes after the shedding of blood most of the ammonium was present as such, and repeated determinations after this time showed only a slow rise. Accordingly, for the purposes of the present paper the level of ammonium three minutes after shedding of blood has been taken as the ammonium content of the specimen. This leaves the question of zero-time ammonium, and rate of liberation to a day when more is known of the sources of blood ammonium and factors affecting its liberation.

It is emphasized that blood ammonia is an erroneous expression since at the $\mathrm{pH}$ of blood less than 1 per cent of ammonia is present in solution as such, the largest amount being in the ionized $\mathrm{NH}_{4}{ }^{+}$form.

\section{METHODS}

Ammonium in blood was determined by a slight modification of Conway's microdiffusion technique (12). Scrupulously washed Conway units were prepared with the central absorbing chamber containing $0.7 \mathrm{ml}$. 1/4000 $\mathrm{N} \mathrm{HCl}$, with Tashiro's reagent as indicator. The outer ring contained $1.0 \mathrm{ml}$. saturated boiled $\mathrm{K}_{2} \mathrm{CO}_{3}$. Fivetenths $\mathrm{ml}$. blood was added to the outer chamber from an accurately calibrated straight pipette. The timing of the blood samples was started with the first appearance of blood in the syringe, and ended when delivery from the pipette was completed. The lid, greased with paraffin-mineral oil mixture was applied, the unit rotated, and then put aside to incubate for 15 minutes at $15^{\circ} \mathrm{C}$. Barium hydroxide, $0.00025 \mathrm{~N}$, delivered from a horizontal pyrex, micrometer driven burette, was used to titrate excess acid. The $\mathrm{Ba}(\mathrm{OH})_{2}$ was kept in a pyrex bottle stoppered with a soda lime trap to exclude $\mathrm{CO}_{2}$. Using this technique titrations of blanks and standards were made with less than 2 per cent error.

After titration of bloods, and simultaneously run standards $\left(\left(\mathrm{NH}_{4}\right)_{2} \mathrm{SO}_{4}\right.$ solution, $0.5 \mu \mathrm{g}$. ammonium nitrogen per ml.) and blanks (reboiled distilled water), the calculated ammonium content of the blood was corrected by a factor of 1.11 , given by Conway (12) to correct for the difference in liberation of $\mathrm{NH}_{3}$ by $\mathrm{K}_{2} \mathrm{CO}_{3}$ from blood and water. Results were then plotted against the recorded time intervals as $\mu \mathrm{g}$. $\mathrm{NH}_{4} \cdot$ nitrogen per $\mathrm{ml}$.

A check was kept on two time intervals; the first the elapsed time between drawing the blood and pipetting into the units, and the second the fifteen-minute incubation period. The latter was chosen as convenient for our purposes, yet well below the time when ammonium may be liberated from glutamine.

As a check on $\mathrm{NH}_{4} \mathrm{Cl}$ absorption, as well as to measure the most important end product of $\mathrm{NH}_{4}$ metabolism, blood urea determinations were made by a sensitive 
technique, accurate to \pm 1 per cent (12). Blood glutamine measurements were made by the method of Boulanger and Osteux (19) accurate to \pm 10 per cent.

For the ammonium tolerance test ammonium chloride, $3.0 \mathrm{gm}$. was given by mouth in gelatin capsules, and almost invariably provoked nausea, rarely vomiting.

Blood samples were taken simultaneously from an antecubital vein and through a catheter passed under fluoroscopic control into an hepatic vein. Specimens were drawn during the control period and 30,60, and 120 minutes after $\mathrm{NH}_{4} \mathrm{Cl}$ ingestion. Blood was collected in clean dry syringes without hemostasis. Boiled, $\mathrm{NH}_{4}$ free potassium oxalate was used as the anticoagulant, as heparin was found to liberate $\mathrm{NH}_{3}$ in the Conway unit.

Urine collections were made on 12 patients to measure $\mathrm{NH}_{4}$ and urea output before and after $\mathrm{NH}_{4} \mathrm{Cl}$ ingestion. The inability to obtain adequate urine flow, especially in cirrhotic patients, vitiated the significance of the measurements, and the effort was abandoned.

On nine occasions renal vein blood was obtained by catheterization. Blood was also taken from abdominal wall collateral veins in two patients with cirrhosis, and from various portal vein radicles in four patients at laparotomy, performed to explore the biliary system in three and for sub-total gastrectomy in one.

\section{PATIENTS}

The patients were divided by diagnosis into several groups.

I. No liver disease, 11 cases. These were hospital staff, 5, and patients suffering from chronic pulmonary or cardiac disease, who had normal liver function tests. They were studied at the time of cardiac catheterization for other purposes.

II. Acute virus hepatitis, 6 cases. This included both mild and severe cases. Two were again investigated during convalescence.

III. Cirrhosis, 26 patients. No distinction was made in this group between biliary cirrhosis ( 3 cases) and portal cirrhosis (23 cases). All of these patients had definite evidence of portal collateral vessels, demonstrated by contrast radiography, esophagoscopy, and/or portal venography (20). Three other patients who had cirrhosis without demonstrable portal collateral vessels were also studied.

IV. Miscellaneous, 8 cases. This diverse group included two with obstructive jaundice due to carcinoma, two with nephritis (one of whom was uremic), two with hepatosplenomegaly and normal liver function tests, one of whom had a normal liver biopsy. The other had abdominal tuberculosis. One patient presented the Chiari syndrome with invasion of the inferior vena cava and hepatic veins by renal carcinoma. One patient had a thrombosed portal vein following pylephlebitis, with esophageal varices and a normal liver by biopsy and function tests.

One patient with cirrhosis and two with normal liver function received no $\mathrm{NH}_{4} \mathrm{Cl}$, but had serial determinations of blood ammonium throughout the day while fasting to investigate diurnal variation.

The neurological signs and symptoms associated with liver disease have been extensively reviewed and are not described here. Of the patients investigated ten had such neurological changes associated with hepatitis or cirrhosis and are fully described elsewhere (9).

\section{RESULTS}

The mean "three-minute" fasting blood ammonium value in 21 control patients without liver disease was $0.79 \mu \mathrm{g}$. per ml., Standard Deviation 0.09 .

In two patients with renal disease and normal liver function tests and one patient with cirrhosis and esophageal varices, one-half to two hourly blood samples were taken throughout the day while the patient fasted, and the fluctuation of ammonium levels was found not to exceed $0.1 \mu \mathrm{g}$. per $\mathrm{ml}$. in antecubital or hepatic vein blood.

In seven resting control subjects simultaneous artery and vein blood samples were obtained from an extremity, and no significant difference in ammonium content at these two sites was observed. Other workers have reported similar results (21, 22).

In five patients the values for portal venous blood ammonium, obtained at laparotomy or from abdominal wall collaterals, averaged 2.7 times those for peripheral blood (Table I). In a further patient $(\mathrm{Ru})$ blood from a gastric vein was

TABLE I

Ammonium content of portal vein blood, with comparison of peripheral vein ammonium level, before and after $\mathrm{NH}_{4} \mathrm{Cl}$ ingestion *

\begin{tabular}{|c|c|c|c|}
\hline Patient & Diagnosis & $\begin{array}{l}\text { Portal } \\
\text { vein }\end{array}$ & $\begin{array}{c}\text { Periphera } \\
\text { vein }\end{array}$ \\
\hline $\begin{array}{l}\mathrm{Br} \\
\mathrm{To} \\
\mathrm{Ne} \\
\mathrm{Me}\end{array}$ & $\begin{array}{l}\text { Cirrhosis } \\
\text { Cirrhosis } \\
\text { Cirrhosis } \\
\text { Cirrhosis with }\end{array}$ & $\begin{array}{l}2.65 \\
2.75 \\
4.27\end{array}$ & $\begin{array}{l}1.12 \\
1.04 \\
1.06\end{array}$ \\
\hline Sw & $\begin{array}{l}\text { Eck fistula } \\
\text { Cirrhosis }\end{array}$ & $\begin{array}{l}4.39 \\
3.67\end{array}$ & $\begin{array}{l}2.53 \\
0.89\end{array}$ \\
\hline $\mathrm{Ru}$ & $\begin{array}{l}\text { Average } \\
\text { Carcinoma } \\
\text { (Blood from } \\
\text { gastric vein) }\end{array}$ & 3.55 & 1.33 \\
\hline To & \multicolumn{2}{|c|}{$\begin{array}{lc}\text { After } 3.0 \mathrm{gm} . \mathrm{NH}_{4} \mathrm{Cl} \text { by mouth } \\
\text { Control } & 2.26 \\
60 \text { minutes } & 6.48\end{array}$} & $\begin{array}{l}1.04 \\
2.75\end{array}$ \\
\hline $\mathrm{Ne}$ & $\begin{array}{l}\text { Control } \\
60 \text { minutes }\end{array}$ & $\begin{array}{l}4.27 \\
6.83\end{array}$ & $\begin{array}{l}1.07 \\
1.52\end{array}$ \\
\hline
\end{tabular}

* Ammonium expressed as $\mu \mathrm{g}$. $\mathrm{NH}_{4} \cdot$ Nitrogen per $\mathrm{ml}$. 
TABLE II

Ammonium content of renal vein blood, with comparison of peripheral vein ammonium level *

\begin{tabular}{clcc}
\hline \hline Patient & \multicolumn{1}{c}{ Diagnosis } & $\begin{array}{c}\text { Renal } \\
\text { vein }\end{array}$ & $\begin{array}{c}\text { Peripheral } \\
\text { vein }\end{array}$ \\
\hline $\mathrm{Th}$ & Tuberculosis & 1.01 & 0.51 \\
$\mathrm{Me}$ & Cirrhosis & 1.21 & 0.79 \\
$\mathrm{Pe}$ & Cirrhosis & 1.35 & 0.99 \\
$\mathrm{Da}$ & Cirrhosis & 1.42 & 0.94 \\
$\mathrm{Me}$ & Cirrhosis with & 1.42 & 2.03 \\
$\mathrm{Ea}$ & Eck fistula & 3.10 & 2.22 \\
$\mathrm{El}$ & Cirrhosis & 2.87 & 2.21 \\
$\mathrm{Sw}$ & Cirrhosis & 0.71 & 0.81 \\
$\mathrm{Au}$ & Cirrhosis & 3.07 & 1.96 \\
& Hepatitis & 1.82 & 1.39 \\
& & Average & 1.82 \\
\hline
\end{tabular}

* Expressed as $\mu \mathrm{g}$. $\mathrm{NH}_{4} \cdot \mathrm{Nitrogen}$ per $\mathrm{ml}$.

found to have a low $\mathrm{NH}_{4}$ content. $\mathrm{NH}_{4} \mathrm{Cl}$ given by mouth to two patients with abdominal wall portal collaterals caused a rise in ammonium in peripheral vein blood, as well as in the portal collateral. In the latter the rise was to a higher absolute level, but in terms of per cent was not greatly different (Table I).

In nine patients (eight with liver disease, one with normal function tests) renal vein ammonium values averaged 30 per cent higher than peripheral vein (Table II). The height of the values was exaggerated because of the inclusion of patients with severe liver disease. Two patients with liver

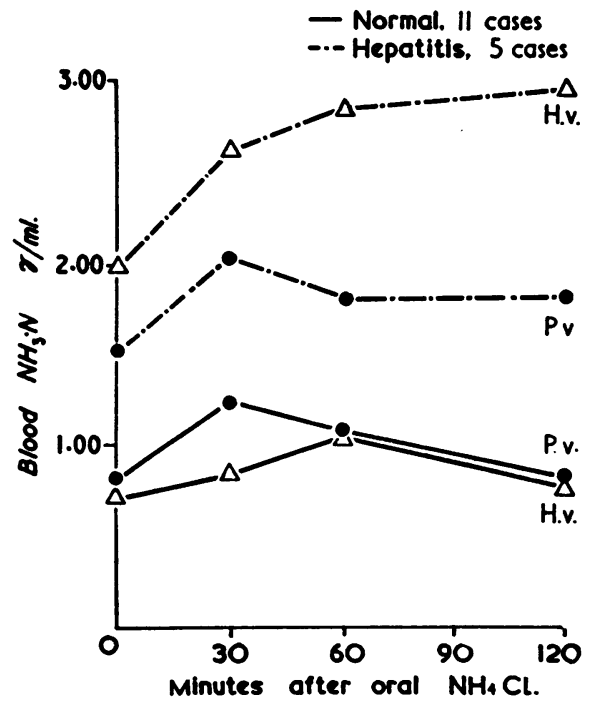

Fig. 2. Ammonium Tolerance Tests, $3.0 \mathrm{gm}$. $\mathrm{NH}_{4} \mathrm{Cl}$ by Mouth, Comparing Control Patients (Normals) with Patients with Hepatitis

P.V.-peripheral vein H.V.-hepatic vein. disease had values in the renal vein lower than in peripheral vein blood. In one of these the peripheral vein ammonium was abnormally high.

\section{Ammonium tolerance tests}

Controls. In eleven control subjects the mean value of ammonium in peripheral vein blood was slightly above that of the hepatic vein. After the ingestion of $\mathrm{NH}_{4} \mathrm{Cl}$ the ammonium content of peripheral vein blood rose moderately with a rapid subsequent decline. The hepatic vein level rose more slowly, and continued to rise for a longer period. Both returned to control levels

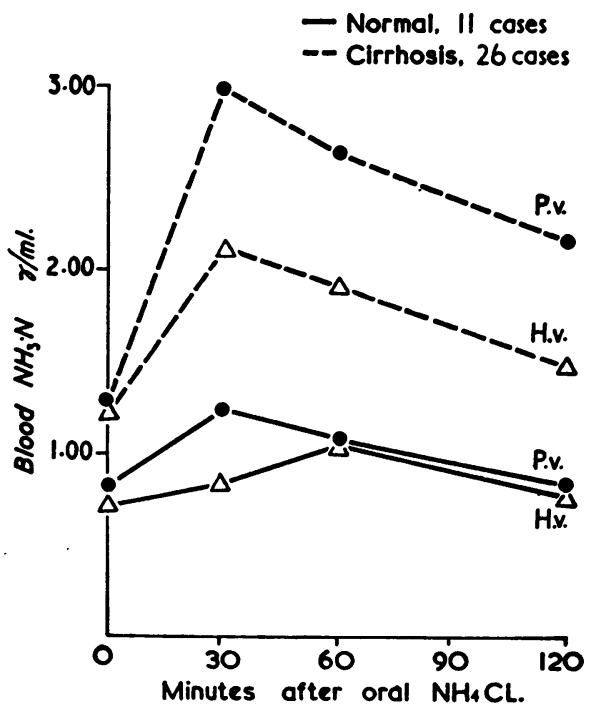

Fig. 3. Ammonium Tolerance Tests, $3.0 \mathrm{gm}$. $\mathrm{NH} . \mathrm{Cl}$ by Mouth, Comparing Control Patients (Normals) with Patients with Cirrhosis and Portal Collateral Circulation

P.V.-peripheral viein H.V.-hepatic vein.

in 120 minutes. No control patient showed any abnormality of central nervous system function before or during the test.

Hepatitis. Four of the five patients studied during the acute phase of viral hepatitis showed elevated peripheral and hepatic vein ammonium levels in control specimens (Figure 2). In three of the four the hepatic vein ammonium content exceeded that of the antecubital vein blood. This became particularly marked after $\mathrm{NH}_{4} \mathrm{Cl}$ ingestion, when the rise in ammonium values in hepatic vein blood far surpassed that of peripheral vein blood. Further, the return to control values was 
delayed, and ammonium levels were above con- hepatitis, whose only abnormal liver function test trol at 120 minutes in both peripheral and hepatic was an elevated bilirubin, but who had biopsy vein blood. The one real exception to these find- evidence of hepatitis. These data suggested ings was in a patient with mild, though acute that in patients with severe hepatitis ammonium

TABLE III

Ammonium tolerance tests in 51 patients. $3.0 \mathrm{gm}$. $\mathrm{NH}_{4} \mathrm{Cl}$ by mouth $\dagger, \ddagger$

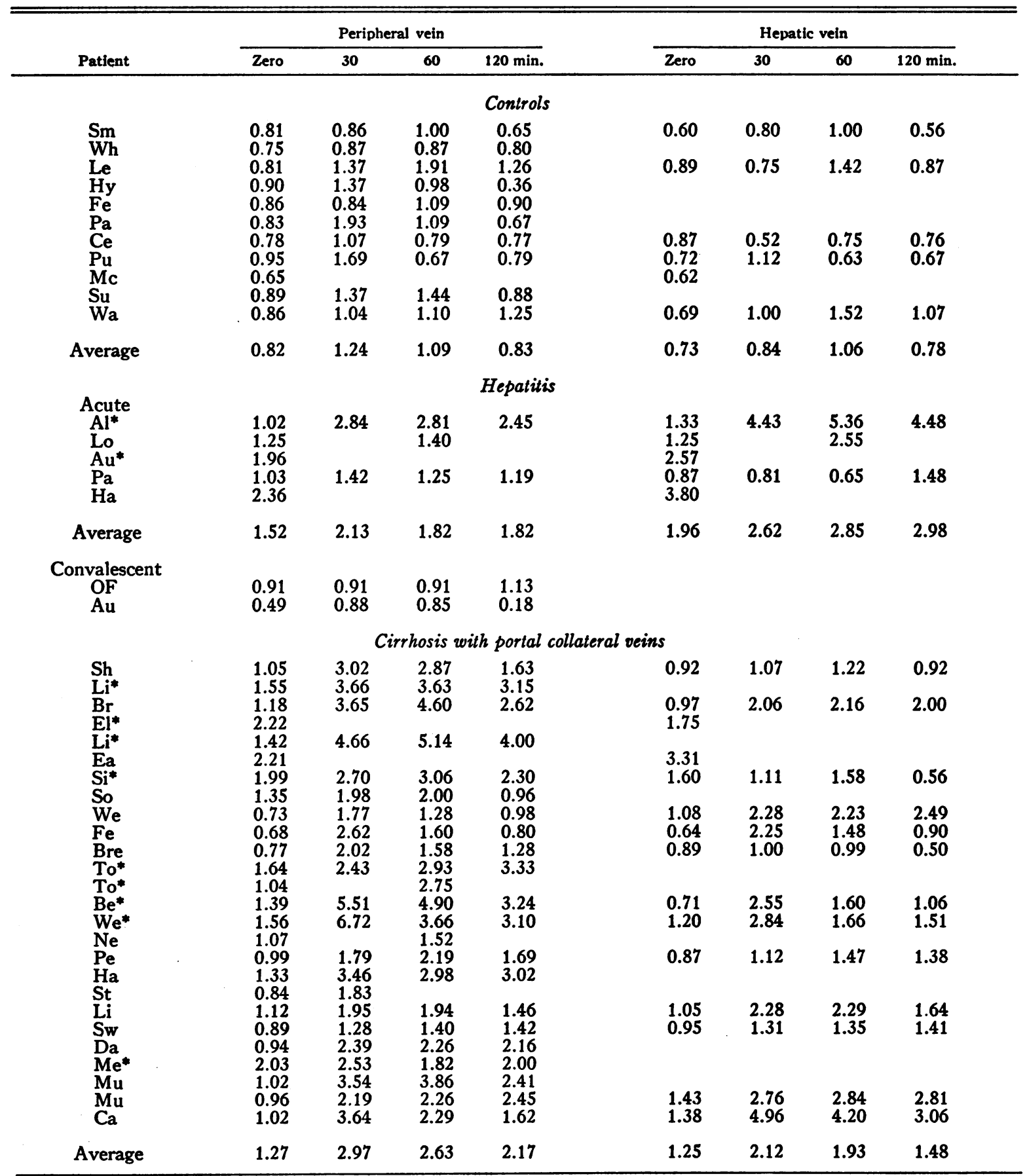


TABLE III-Continued

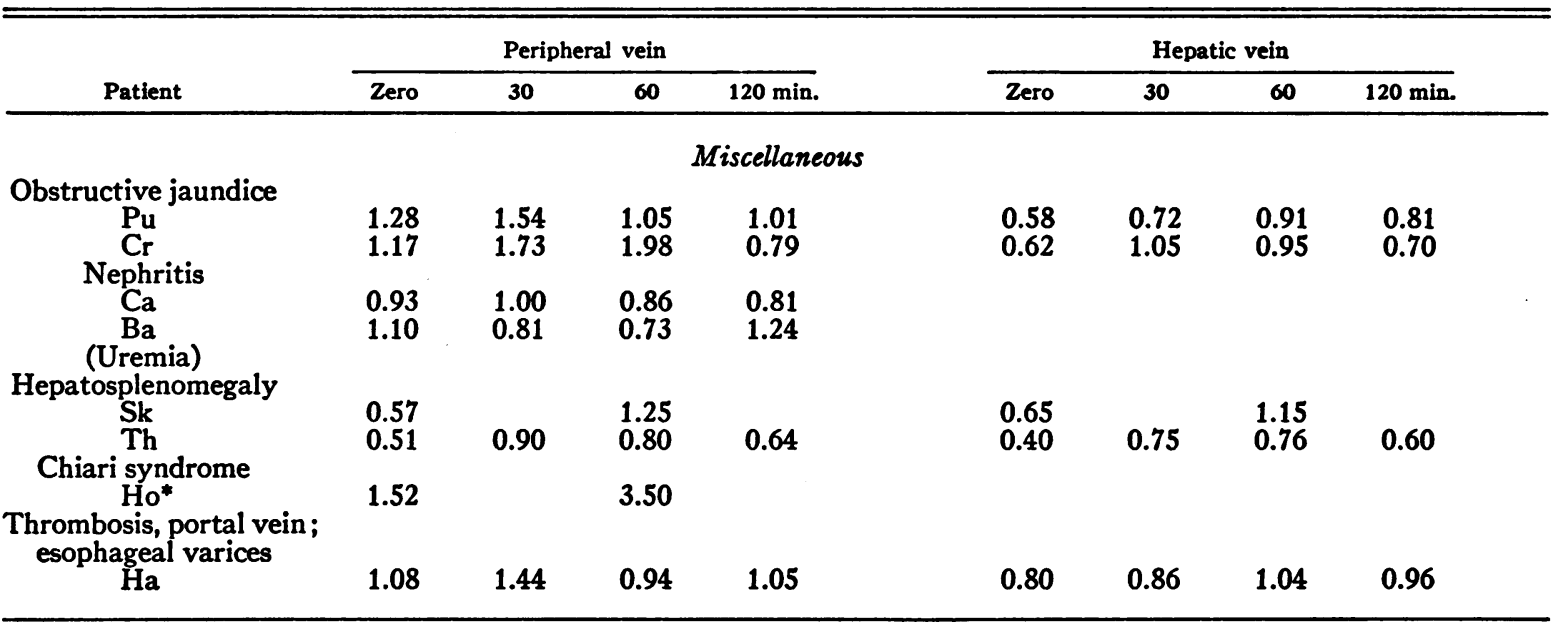

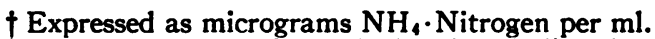

$\ddagger$ All averages were first calculated excluding data where there were not simultaneous peripheral and hepatic vein samples. As this is a result almost identical to that obtained from averaging all the data, the latter averages have been given.

* These patients had neurological disturbances at some time during the course of their illnesses.

from the intestine passed through the damaged liver and so reached the systemic circulation.

One patient developed a tremor after the ingestion of $\mathrm{NH}_{4} \mathrm{Cl}$ and this symptom persisted for three days.

Two patients in the convalescent stage of hepatitis, with normal liver function tests were found to have normal ammonium tolerance curves in peripheral blood.

Cirrhosis. The 26 patients who had cirrhosis and portal vein collateral circulation had higher average $\mathrm{NH}_{4}$ values in peripheral and hepatic vein blood in the fasting state than did control subjects (Figure 3, Table III). After ingestion of $\mathrm{NH}_{4} \mathrm{Cl}$ the ammonium content of peripheral vein blood rose to a very high level at 30 minutes, far exceeding the average concomitant rise in $\mathrm{NH}_{4}$ values in hepatic vein blood. Both fell at a rate equal to that of controls, but both were significantly above fasting values at 120 minutes. The vast increase in $\mathrm{NH}_{4}$ content of peripheral vein blood could not be accounted for, in these patients, by ammonium in the hepatic vein blood, and large amounts must have reached the peripheral blood by portal collateral channels.

Four of these patients were studied at a time when tremor and mental confusion were present; during the test their symptoms were exaggerated.

Three patients with cirrhosis who did not have demonstrable portal collateral veins, had normal ammonium tolerance tests in peripheral and hepatic vein blood.

Despite the striking differences between patients with cirrhosis and portal venous collaterals and patients with hepatitis, individual cases showed some variations. In one patient with cirrhosis, large portal collateral veins and excellent liver function by standard tests, the ammonium content of peripheral blood rose to high levels after $\mathrm{NH}_{4} \mathrm{Cl}$ ingestion; $\mathrm{NH}_{4}$ values in hepatic vein blood increased only slightly and were below the

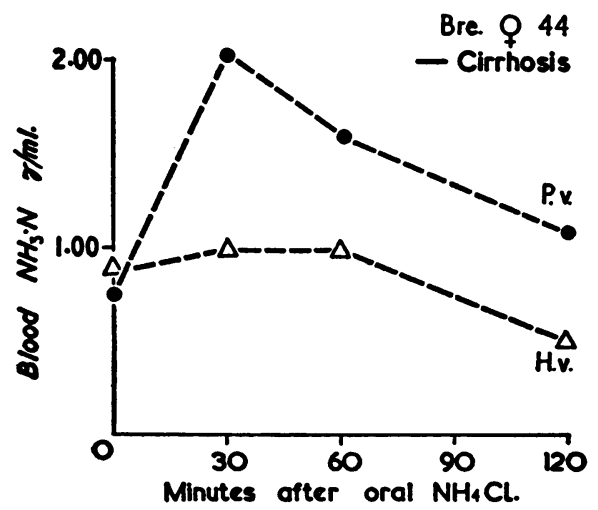

Fig. 4. Ammonium Tolerance Test, $3.0 \mathrm{gm}$. $\mathrm{NH}_{4} \mathrm{Cl}$ by Mouth, in a Single Patient with Cirrhosis, Esophageal Varices and Good Liver Function

P.V.-peripheral vein H.V.-hepatic vein. 
fasting level at 120 minutes (Case Bre, Figure 4). This response demonstrated the importance of collateral channels in the production of abnormal ammonium tolerance in some patients with good liver function. Conversely, in an additional patient with cirrhosis, portal collateral veins and poor liver function (elevated bilirubin, abnormal thymol turbidity and low serum albumin), a marked increase in ammonium levels in blood followed the ingestion of $\mathrm{NH}_{4} \mathrm{Cl}$ and was more marked in hepatic vein blood than in peripheral vein blood. Ammonium values at both sites were above the fasting at 120 minutes (Case Can, Figure 5). This case demonstrated that in cirrhosis with poor liver function $\mathrm{NH}_{4}$ may pass through the damaged liver into the general circulation.

Miscellaneous. Two patients with obstructive jaundice due to carcinoma showed elevated peripheral vein ammonium levels in control, 30 and 60

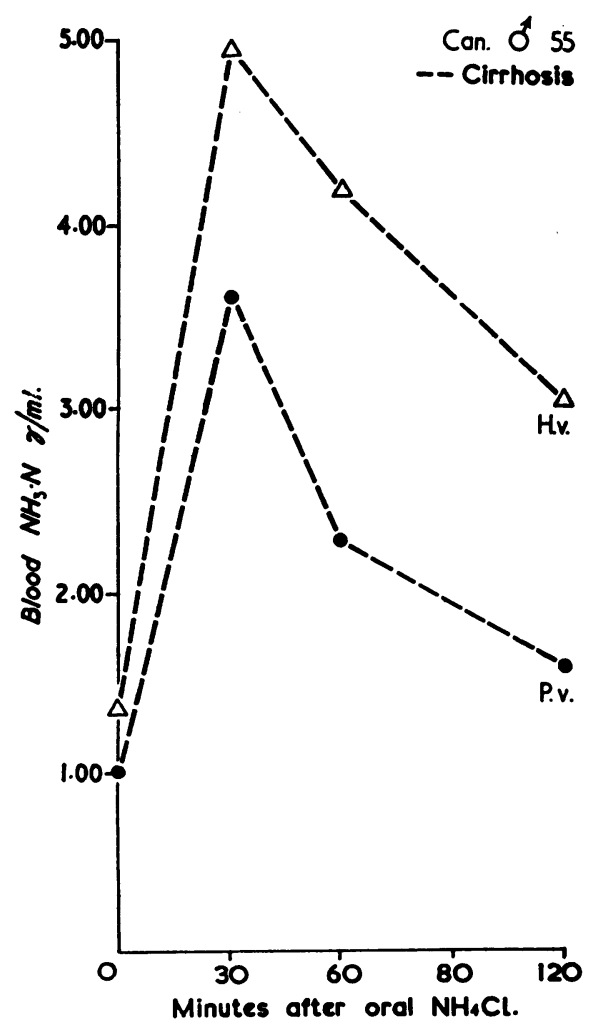

Fig. 5. Ammonium Tolmance Test, $3.0 \mathrm{gm}$. $\mathrm{NH}_{4} \mathrm{Cl}$ by Mouth, in a Patient with Cirrhosis, Extensive Portal Collateral Channels and Poor Liver Function

Despite the high level of $\mathrm{NH}_{4}$ he experienced no neurological disturbance during the test.

P.V.-peripheral vein H.V.-hepatic vein.

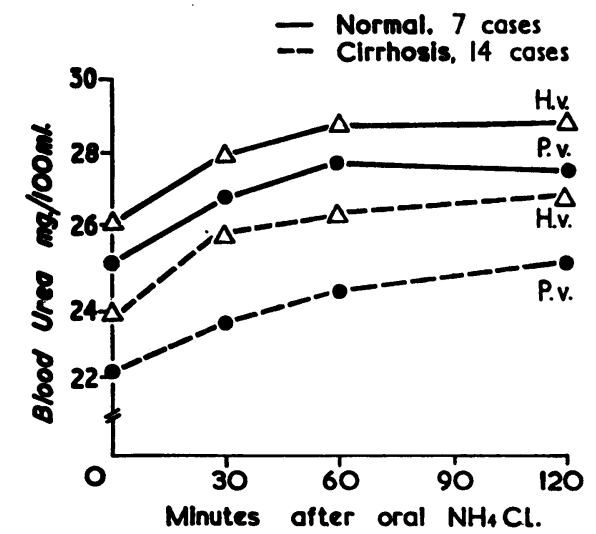

Fig. 6. Blood Urea Determinations During the Ammonium Tolerance Test

Values in control patients compared with those in patients with cirrhosis.

$$
\text { P.V.-peripheral vein H.V.-hepatic vein. }
$$

minute specimens, but 120 -minute values were below the fasting levels. The hepatic vein $\mathrm{NH}_{4}$ values were within normal limits (Table III).

One patient with nephritis showed a normal ammonium tolerance curve in peripheral vein blood. A second patient, with nephritis and uremia (blood urea $418 \mathrm{mg}$. per $100 \mathrm{ml}$ ) had a fall in peripheral blood $\mathrm{NH}_{4}$ after $\mathrm{NH}_{4} \mathrm{Cl}$ ingestion, with a late rise (Table III).

The two patients with hepatosplenomegaly and normal liver function tests showed ammonium tolerance tests within normal limits in both peripheral and hepatic vein blood.

The patient with the Chiari syndrome had an elevated blood $\mathrm{NH}_{4}$ in the fasting peripheral vein blood, and this rose higher 60 minutes after the ingestion of $\mathrm{NH}_{4} \mathrm{Cl}$.

The patient with normal liver, thrombosed portal vein and extensive esophageal varices secondary to pylephlebitis, had an elevated $\mathrm{NH}_{4}$ response in peripheral vein blood after $\mathrm{NH}_{4} \mathrm{Cl}$. The hepatic vein figures were within normal limits (Table III).

None of the patients in this miscellaneous group had neurological symptoms at any time before or after $\mathrm{NH}_{4} \mathrm{Cl}$ ingestion.

\section{Blood glutamine studies}

In seven control subjects there was no consistent or significant change in glutamine content of peripheral or hepatic vein blood after $\mathrm{NH}_{4} \mathrm{Cl}$ 
TABLE IV

Blood glutamine during ammonium tolerance tests, comparing levels in peripheral and hepatic vein blood*

\begin{tabular}{|c|c|c|c|c|c|c|c|c|}
\hline \multirow[b]{2}{*}{ Patient } & \multicolumn{4}{|c|}{ Peripheral vein } & \multicolumn{4}{|c|}{ Hepatic vein } \\
\hline & Control & 30 & 60 & $120 \mathrm{~min}$. & Control & 30 & 60 & $120 \mathrm{~min}$. \\
\hline \multicolumn{9}{|c|}{ Controls } \\
\hline $\begin{array}{l}\mathrm{Pa} \\
\text { Fo } \\
\text { Lo } \\
\text { Sm } \\
\text { Hy } \\
\text { Wh } \\
\text { Co } \\
\text { Mc }\end{array}$ & $\begin{array}{r}13.0 \\
8.1 \\
7.4 \\
14.5 \\
12.5 \\
13.6 \\
12.4 \\
10.0\end{array}$ & $\begin{array}{r}13.3 \\
8.4 \\
11.0 \\
12.0 \\
13.4 \\
13.7 \\
11.0\end{array}$ & $\begin{array}{r}12.6 \\
7.8 \\
10.9 \\
15.4 \\
15.4 \\
8.1 \\
8.1\end{array}$ & $\begin{array}{r}12.2 \\
12.9 \\
13.6 \\
12.0 \\
12.5 \\
8.3 \\
11.0\end{array}$ & $\begin{array}{r}9.4 \\
10.2\end{array}$ & $\begin{array}{r}8.7 \\
11.5\end{array}$ & $\begin{array}{l}10.0 \\
12.4\end{array}$ & $\begin{array}{r}9.6 \\
12.0\end{array}$ \\
\hline Average & 11.4 & 11.8 & 11.2 & 11.8 & 9.6 & 9.7 & 10.5 & 10.4 \\
\hline \multicolumn{9}{|c|}{ Cirrhosis } \\
\hline \multirow{7}{*}{$\begin{array}{l}\mathrm{Ga} \\
\mathrm{Sh} \\
\mathrm{Br} \\
\mathrm{Mu} \\
\mathrm{Mu} \\
\mathrm{So} \\
\mathrm{Si} \\
\mathrm{Wo} \\
\mathrm{Ca} \\
\mathrm{Fe} \\
\mathrm{Br} \\
\mathrm{To} \\
\mathrm{Be} \\
\mathrm{Li} \\
\mathrm{Pe}\end{array}$} & \multirow{7}{*}{$\begin{array}{r}6.6 \\
25.0 \\
5.1 \\
9.9 \\
9.8 \\
13.4 \\
13.2 \\
14.2 \\
10.6 \\
7.3 \\
12.1 \\
10.0 \\
13.8 \\
7.1 \\
12.5\end{array}$} & \multirow{5}{*}{$\begin{array}{r}18.2 \\
12.0 \\
12.1 \\
13.2 \\
11.4 \\
11.5 \\
12.6 \\
13.6 \\
17.1 \\
8.3\end{array}$} & \multirow{5}{*}{$\begin{array}{r}9.0 \\
17.1 \\
8.2 \\
14.2 \\
11.6 \\
9.8 \\
9.8 \\
11.8 \\
14.4 \\
12.0 \\
8.7 \\
10.5\end{array}$} & \multirow{5}{*}{$\begin{array}{r}8.6 \\
12.1 \\
10.1 \\
6.1 \\
13.9 \\
7.8 \\
10.2 \\
12.6 \\
15.0 \\
12.7 \\
11.8\end{array}$} & 7.8 & 8.4 & 7.8 & 8.2 \\
\hline & & & & & 56 & 63 & & \\
\hline & & & & & & & 3.8 & 10.3 \\
\hline & & & & & 12.7 & 8.4 & 9.8 & 12.4 \\
\hline & & & & & $\begin{array}{r}11.1 \\
7.7 \\
11.5 \\
10.2 \\
6.4\end{array}$ & $\begin{array}{r}11.9 \\
5.7 \\
12.4 \\
15.1 \\
7.1\end{array}$ & $\begin{array}{r}10.1 \\
10.2 \\
12.4 \\
15.1 \\
7.9\end{array}$ & $\begin{array}{r}13.6 \\
17.9 \\
12.9 \\
19.6 \\
5.6\end{array}$ \\
\hline & & $\begin{array}{l}9.9 \\
6.7\end{array}$ & 8.5 & $\begin{array}{l}11.3 \\
12.2\end{array}$ & 8.8 & 7.7 & 6.3 & 11.3 \\
\hline & & 10.3 & 12.2 & 11.2 & 9.4 & 9.1 & 11.2 & 9.7 \\
\hline Average & 11.4 & 12.1 & 11.3 & 11.1 & 9.1 & 9.2 & 9.5 & 12.2 \\
\hline
\end{tabular}

* Expressed as mg. per $100 \mathrm{ml}$.

TABLE V

Blood urea during ammonium tolerance tests, comparing levels in peripheral and hepatic vein blood*

\begin{tabular}{|c|c|c|c|c|c|c|c|c|}
\hline \multirow[b]{2}{*}{ Patient } & \multicolumn{4}{|c|}{ Peripheral vein } & \multicolumn{4}{|c|}{ Hepatic vein } \\
\hline & Control & 30 & 60 & $120 \mathrm{~min}$. & Control & 30 & 60 & $120 \mathrm{~min}$. \\
\hline \multicolumn{9}{|c|}{ Controls } \\
\hline $\begin{array}{l}\mathrm{Pa} \\
\text { Fo } \\
\text { Lo } \\
\text { Sm } \\
\text { Hy } \\
\text { Wh } \\
\text { Co }\end{array}$ & $\begin{array}{l}25.0 \\
18.1 \\
24.7 \\
20.9 \\
26.0 \\
29.0 \\
31.6\end{array}$ & $\begin{array}{l}26.6 \\
19.7 \\
26.3 \\
19.3 \\
27.0 \\
33.0 \\
35.0\end{array}$ & $\begin{array}{l}26.0 \\
21.7 \\
26.7 \\
21.9 \\
27.5 \\
35.0 \\
35.2\end{array}$ & $\begin{array}{l}21.2 \\
22.5 \\
27.2 \\
21.0 \\
29.0 \\
36.0 \\
35.6\end{array}$ & $\begin{array}{l}24.9 \\
20.5 \\
\\
33.0\end{array}$ & $\begin{array}{l}27.0 \\
21.8 \\
34.9\end{array}$ & $\begin{array}{l}28.1 \\
22.2 \\
35.9\end{array}$ & $\begin{array}{l}27.5 \\
22.2 \\
36.4\end{array}$ \\
\hline Average & 25.0 & 26.7 & 27.7 & 27.5 & 26.1 & 27.9 & 28.7 & 28.7 \\
\hline \multicolumn{9}{|c|}{ Cirrhosis } \\
\hline $\begin{array}{l}\mathrm{Ga} \\
\mathrm{Sh} \\
\mathrm{Br} \\
\mathrm{Mu}\end{array}$ & $\begin{array}{l}28.4 \\
23.3 \\
21.6 \\
20.0\end{array}$ & $\begin{array}{l}41.1 \\
22.6 \\
21.0 \\
20.9\end{array}$ & $\begin{array}{l}42.4 \\
28.6 \\
21.0 \\
23.4\end{array}$ & $\begin{array}{l}43.6 \\
34.2 \\
20.0 \\
24.1\end{array}$ & $\begin{array}{l}37.2 \\
23.2 \\
18.4\end{array}$ & $\begin{array}{l}43.2 \\
23.6\end{array}$ & $\begin{array}{l}44.2 \\
31.3\end{array}$ & $\begin{array}{l}43.0 \\
35.4 \\
22.0\end{array}$ \\
\hline $\begin{array}{l}\mathrm{Mu} \\
\mathrm{Si} \\
\mathrm{Wo} \\
\mathrm{Ca} \\
\mathrm{Fe} \\
\mathrm{Br} \\
\mathrm{Be} \\
\mathrm{Li}\end{array}$ & $\begin{array}{l}20.4 \\
30.7 \\
21.6 \\
25.3 \\
14.8 \\
20.6 \\
25.1 \\
14.6\end{array}$ & $\begin{array}{l}19.2 \\
31.2 \\
23.2 \\
26.2 \\
15.2 \\
19.6 \\
25.6 \\
15.2\end{array}$ & $\begin{array}{l}19.5 \\
31.7 \\
23.4 \\
26.1 \\
15.8 \\
22.4 \\
25.3 \\
14.7\end{array}$ & $\begin{array}{l}19.8 \\
32.1 \\
23.1 \\
27.0 \\
16.2 \\
23.2 \\
26.2 \\
14.6\end{array}$ & $\begin{array}{l}19.0 \\
29.8 \\
23.0 \\
26.8 \\
15.2 \\
22.4 \\
27.0\end{array}$ & $\begin{array}{l}19.7 \\
29.9 \\
22.5 \\
27.2 \\
16.6 \\
23.1 \\
28.2\end{array}$ & $\begin{array}{l}18.8 \\
31.0 \\
21.1 \\
26.9 \\
16.3 \\
25.6 \\
27.8\end{array}$ & $\begin{array}{l}19.8 \\
31.0 \\
25.6 \\
27.6 \\
17.1 \\
24.0 \\
28.6\end{array}$ \\
\hline $\begin{array}{l}\text { We } \\
\mathrm{Me}\end{array}$ & $\begin{array}{l}18.5 \\
24.8\end{array}$ & $\begin{array}{l}20.6 \\
26.0\end{array}$ & $\begin{array}{l}19.1 \\
26.8\end{array}$ & $\begin{array}{l}18.8 \\
27.1\end{array}$ & $\begin{array}{l}18.6 \\
24.0\end{array}$ & $\begin{array}{l}21.0 \\
27.4\end{array}$ & $\begin{array}{l}18.8 \\
28.2\end{array}$ & $\begin{array}{l}19.6 \\
28.0\end{array}$ \\
\hline Average & 22.1 & 23.4 & 24.3 & 25.0 & 23.7 & 25.7 & 26.4 & 26.8 \\
\hline
\end{tabular}

* Expressed as mg. per $100 \mathrm{ml}$. 
ingestion (Table IV). Similarly, in fourteen patients with cirrhosis there was no consistent response in blood glutamine to the administration of $\mathrm{NH}_{4} \mathrm{Cl}$ by mouth. Individual cases varied widely, but averages showed no significant differences. Values below those of peripheral vein blood were obtained in two patients from renal vein blood.

\section{Blood urea studies}

Blood urea increased in seven control subjects and in fourteen patients with cirrhosis after $\mathrm{NH}_{4} \mathrm{Cl}$ ingestion (Table V). Quantitatively the total rise was equal in the two groups, and the rate of rise was similar (Figure 6).

\section{DISCUSSION}

The data presented suggest two main sources of what is presently measured as blood ammonium in resting subjects: 1) The gastrointestinal tract; and 2) the kidneys. These results agree with previously published observations $(1,2,21,22)$.

The proof that a substance, or substances, from intestinal contents may provoke systemic disturbances must rest on three factors: 1) That the material must be absorbed in sufficient quantity from the intestine; 2 ) that it must then enter the general circulation in abnormal amounts; and 3) provoke toxic manifestations.

The data reported here confirm that $\mathrm{NH}_{4} \mathrm{Cl}$ fulfills the first two of these requirements in patients with severe liver disease. The high fasting level of ammonium in portal blood and its rapid rise after an oral dose of $\mathrm{NH}_{4} \mathrm{Cl}$ prove its rapid absorption (23).

The small increase in peripheral blood ammonium levels after $\mathrm{NH}_{4} \mathrm{Cl}$ ingestion in control subjects is in marked contrast to results observed in patients with liver disease. In patients with severe acute hepatitis, or cirrhosis with poor liver function, the normal high gradient between ammonium content of portal and hepatic venous blood is diminished, and large amounts of ammonium reach the general circulation through the liver. In patients with good liver function, but with extensive portal collateral circulation, high peripheral blood ammonium levels may follow the ingestion of $\mathrm{NH}_{4} \mathrm{Cl}$. In these patients, however, the $\mathrm{NH}_{4}$ gradient from portal to hepatic venous blood is normal, indicating that ammonium entered the peripheral circulation through some route other than hepatic veins, probably through the portal collateral channels. In patients with poor liver function and portal collateral veins both routes exist, and high levels of ammonium are found in peripheral blood. These results demonstrate the pathways taken by ammonium from intestine to peripheral blood, and confirm for $\mathrm{NH}_{4} \mathrm{Cl}$ the second of the above factors.

Evidence was also obtained for the third factor, that $\mathrm{NH}_{4} \mathrm{Cl}$ is, in fact, toxic. Five patients showed accentuation of neurological disturbances during the $\mathrm{NH}_{4} \mathrm{Cl}$ tolerance test. Such symptoms were found only in those patients in whom the $\mathrm{NH}_{4}$ levels remained elevated for a considerable period. Not all of the patients with prolonged high peripheral blood ammonium levels developed neurological symptoms, and such disturbances occurred in others when blood ammonium was only moderately elevated (9). There was no evidence of acidosis in any patient (9).

It is, at present, impossible to state that ammonium itself is the toxic substance, or to explain the mechanism of toxicity. It is certain that ammonium, or some material derived from it, can produce toxic changes in the central nervous system. Other nitrogenous substances may have a similar effect (6).

The rise in ammonium level of hepatic vein blood after an oral dose of $\mathrm{NH}_{4} \mathrm{Cl}$ is a sensitive index of the capacity of the liver to metabolize ammonium, and therefore of hepatocellular function.

The present investigation cast no light on the metabolic abnormality in these patients. In the patients with portal collateral veins, the shunting of blood away from the normal site of ammonium metabolism could itself be responsible for high $\mathrm{NH}_{4}$ levels in peripheral blood. In the presence of poor liver function, however, some abnormality in the metabolism of $\mathrm{NH}_{4}$ in the liver is obvious. Little can be deduced of the role of glutamine synthesis in this mechanism from the present data. Glutamine is, however, quantitatively of minor importance as an end product of ammonium metabolism. Of far more importance is urea, the formation of which is primarily an hepatic function (24, 25). In these studies no difference between nor- 
mal and cirrhotic subjects was found in the ability to synthesize urea.

Ammonium tolerance tests in the miscellaneous group of patients demonstrated an abnormal response in two patients with obstructive jaundice and one patient with the Chiari syndrome. No explanation is apparent for this abnormality in obstructive jaundice. The essentially normal response in the one patient with thrombosed portal vein, esophageal varices and good liver function must be regarded as unexplained, except insofar as all biological material varies in response.

\section{CONCLUSIONS}

1. In resting patients without liver disease there is no measurable ammonium in the circulating peripheral blood. Three minutes after shedding of blood appreciable amounts of ammonium have appeared, and this represents what is usually called blood ammonium.

2. Fifty-one ammonium tolerance tests have shown that patients with severe liver disease, following an oral dose of $3.0 \mathrm{gm}$. of ammonium chloride, exhibited an abnormally elevated ammonium content of peripheral vein blood.

3. Hepatic vein catheterization demonstrated that this abnormality was related to the failure of the liver to metabolize ammonium normally and/or to the presence of portal collateral veins, diverting high ammonium content portal blood around the liver.

4. Five of the patients with abnormal ammonium tolerance tests showed neurological symptoms during the test.

\section{REFERENCES}

1. Nencki, M., Pawlow, J. P., and Zaleski, J., Ueber den Ammoniakgehalt des Blutes und der Organe die Hernstoffbildung bei den Säugetieren. Arch. f. exper. Path. u Pharmakol., 1895, 37, 26.

2. Kirk, E., Amino acid and ammonia metabolism in liver diseases. Acta med. Scandinav., 1936, Suppl. LXXVII, 1.

3. Van Caulaert, C., Deviller, Ch., and Halff, M., Le Taux de l'Ammoniémie dans certaines affections hépatiques. Compt. rend. Soc. de biol., 1932, 111, 735.

4. Stokes, J. F., Owen, J. R., and Holmes, E. G., Neurological complications of infective hepatitis. Brit. Med. J., 1945, II, 642.
5. Walshe, J. M., Observations on the symptomatology and pathogenesis of hepatic coma. Quart. J. Med., 1951, 20, 421.

6. Phillips, G. B., Schwartz, R., Gabuzda, G. J., Jr., and Davidson, C. S., The syndrome of impending hepatic coma in patients with cirrhosis of the liver given certain nitrogenous substances. New England J. Med., 1952, 247, 239.

7. Adams, R. D., and Foley, J. M., The neurological disorder associated with liver disease. Research Publ., A. Res. Nerv. \& Ment. Dis., 1953, 32, 198.

8. McDermott, W. V., Jr., and Adams, R. D., Episodic stupor associated with an Eck fistula in the human with particular reference to the metabolism of ammonia. J. Clin. Invest., 1954, 33, 1.

9. Sherlock, S., Summerskill, W. H. J., White, L. P., and Phear, E. A., Portal-systemic encephalopathy: neurological complications of liver disease. Lancet, 1954, II, 453.

10. Van Caulaert,. C., Deviller, Ch., and Halff, M., Troubles Provoqués par l'Ingestion de Sels Ammoniacaux chez l'Homme Atteint de Cirrhose de Laënnec. Compt. rend. Soc. de biol., 1932, 111, 739.

11. Herrick, R., The Night Piece, to Julia. 1591-1678.

12. Conway, E. J., Microdiffusion Analysis and Volumetric Error. 3rd Ed., London, Crosby, Lockwood and Son, 1950.

13. Conway, E. J., and Cooke, R., Blood ammonia. Biochem. J., 1939, 33, 457.

14. Conway, E. J., and Cooke, R., Blood ammonia and the deaminases of adenosine and adenylic acid. Nature, 1938, 142, 720.

15. Strehler, E., Haas, J., and Rupp, F., Der Einfluss von $\mathrm{CO}_{2}$ auf den Ammoniakgehalt des Blutes in Vitro. Biochem. Ztschr., 1942, 313, 170.

16. Kalckar, H. M., Differential spectrophotometry of purine compounds by means of specific enzymes. III. Studies of the enzymes of purine metabolism. J. Biol. Chem., 1947, 167, 461.

17. Traeger, H. S., Gabuzda, G. J., Jr., Ballou, A. N., and Davidson, C. S., Blood "ammonia" concentration in liver disease, and liver coma. Metabolism, 1954, 3, 99.

18. Zittle, C. A., Adenosine deaminase from calf intestinal mucosa. J. Biol. Chem., 1946, 166, 499.

19. Boulanger, P., and Osteux, R., Méthode de Dosage de la Glutamine dans le Plasma Sanguin. Bull. Soc. chim. biol., 1949, 31, 1290.

20. Atkinson, M., Barnett, E., Sherlock, S., and Steiner, $R$., The clinical investigation of the portal venous circulation with particular reference to transsplenic portal venography. Quart. J. Med., 1955. In press.

21. Nash, T. P., Jr., and Benedict, S. R., The ammonia content of the blood, and its bearing on the mechanism of acid neutralization in the animal organism. J. Biol. Chem., 1921, 48, 463. 
22. Parnas, J. K., and Klisiecki, A., Uber den Ammoniakgehalt und die Ammoniakbildung im Blute. VI. Mitteilung: Experimentelle Untersuchungen über die Faktoren welche den Ammoniakgehalt des kreisenden Blutes Beeinflussen, und über die Lokalisation der Ammoniakbildung und des Ammoniakschwundes beim Kaninchen. Biochem Ztschr., 1926, 173, 224.

23. McDonald, I. W., The absorption of ammonia from the rumen of the sheep. Biochem. J., 1948, 42, 584.

24. Krebs, H. A., Urea synthesis in The Enzymes, ed. by Sumner, J. B., and Myrbäck, K., New York, Academic Press, 1952, vol. 2, part 2, p. 866.

25. Ratner, S., Urea formation in Symposium on Phosphorus Metabolism, ed by McElroy, W. D., and Glass, B., Baltimore, Johns Hopkins Press, 1951, vol. 1, p. 601 .

\section{SPECIAL NOTICE TO SUBSCRIBERS}

Post Offices will no longer forward the Journal when you move.

Please notify The Journal of Clinical Investigation, Business Office, 622 West 168th Street, New. York 32, N. Y. at once when you have a change of address, and do not omit the zone number if there is one. 